\title{
Capacity Building for the Integration of Climate Adaptation into Urban Planning Processes: The Dutch Experience
}

\author{
Thomas Hartmann, Tejo Spit \\ Urban and Regional Research Centre Utrecht, Utrecht University, Utrecht, The Netherlands \\ Email: t.hartmann@uu.nl
}

Received 16 June 2014; revised 15 July 2014; accepted 12 August 2014

Copyright (C) 2014 by authors and Scientific Research Publishing Inc.

This work is licensed under the Creative Commons Attribution International License (CC BY). http://creativecommons.org/licenses/by/4.0/

(c) (i) Open Access

\begin{abstract}
The institutions of the Dutch (urban) planning system face four challenging characteristics of climate adaptation measures. These measures are uncertain in their effects, in competition with other interests, multifaceted, and inherently complex. Capacity building is a key issue for the implementation of climate adaptation measures in urban planning processes, which aim to achieve Climate-Proof Cities (CPC). For successful capacity building, it is important to define the relevant stakeholders and tailor the adaptation strategies first to (the position of) these stakeholders and next to the specific urban conditions and issues. In addition, scientific insights and tools can be of assistance, and the use of climate maps can help to create a common language. Such common understanding of climate problems can lead to "goal entwinement" between actors, which can support the implementation of climate adaptation strategies in urban planning. Awareness, recognition and urgency are the most important components of this common understanding, which may differ for each stage in every urban planning process. In order to overcome the pragmatism that rules in day-to-day urban planning processes, multi-level arrangements between different tiers of government must be employed to improve the penetration of climate adaptation measures. After all, it still remains a soft interest in a hard process.
\end{abstract}

\section{Keywords}

Climate Adaptation, Urban Planning, Netherlands, Policy Integration, Climate-Proof Cities

\section{Introduction}

Throughout the world, cities in delta areas must deal with the effects of climate change. Over time, in the Nether-

How to cite this paper: Hartmann, T. and Spit, T. (2014) Capacity Building for the Integration of Climate Adaptation into Urban Planning Processes: The Dutch Experience. American Journal of Climate Change, 3, 245-252.

http://dx.doi.org/10.4236/ajcc.2014.33023 
lands, the awareness and the sense of urgency for climate adaptation have grown. The latter can easily be understood when one considers that the Dutch authorities have to deal with rising sea levels as well as rising river discharges. Heavy rainfalls and rising ground water levels are also matters of concern. Therefore, water threatens Dutch cities from multiple sides. Of course, other effects of climate change include heavy winds and urban heat islands, but these seem less important within the Dutch context, where water is clearly the dominant issue, as most of the country lies below sea level. Dutch local governments have only recently started to explore the possibilities of coping with the effects of climate change in terms of adaptation in urban planning. In this vein, the Climate-Proof City Programme (CPC) has been launched. The types of adaptation planned in this program anticipate climate changes that can already be observed; the adaptations include different kinds of structural measures, such as adjustments in urban design, temporal water storages etc. [1].

In this contribution, we explore the possibilities of integrating climate adaptation measures in urban planning processes in the Netherlands.

The results are based on the early experiences of some of the larger municipalities in the Netherlands that participate in the Knowledge for Climate research programme (KFC). These municipalities are Amsterdam, Rotterdam, The Hague and Arnhem. Practical experience in integrating climate adaptation measures is rather new, and it is mainly limited (until now) to policy making and small technical adjustments, as examples in Rotterdam and Amsterdam have shown [1] [2]. Therefore, the analysis remains mostly theoretical and explorative. Also, as the debate on this integration is rather fierce, we intend to shed some light on the dilemmas that are revealed by this debate, as we expect that similar dilemmas will emerge throughout the world.

The very subject of climate change brings along with it specific challenges. These challenges, related to climate adaptation, are identified in the next section. Because these challenges are dealt with at the local level, a short outline of the institutional background of Dutch urban planning follows to aid the reader's understanding of the context of the challenges. Next, a sketch of the dilemmas related to climate adaptation in the context of urban planning will be presented. Finally, a three-stage procedure for facing these dilemmas will be proposed that leads to capacity building for the integration of climate adaptation into urban planning processes.

\section{Challenges of Climate Adaptation}

Research within the KFC and CPC identified many types of challenges that planning systems and planning processes face when attempting to implement climate adaptation measures. Van Buuren et al. defined four types of such challenges [3].

\subsection{Specific Uncertainties}

The first type of challenge is that the planning system has to deal with the uncertainties that come along with the issue of climate change. Although knowledge about climate change (see the IPCC reports) and its effects is increasing [3]-[6], much uncertainty remains regarding the degree, the time, and the manner in which climate change will affect local communities. This uncertainty can result in indecisiveness and hesitation [7]. Responding to this uncertainty is thus crucial for climate-proof cities.

\subsection{Competing Issues}

The second challenge comes from the competition of climate change with other interests, particularly in spatial planning. Within local spatial planning processes, the issue of climate adaptation has to compete with other interests. Additionally, some sort of cost-benefit balance must always be taken into account. As climate adaptation measures mostly require a long-term horizon, they can quickly transform into a so-called weak interest in local decision-making processes. A good example for such measures can be found in the way the municipality of Arnhem is trying to incorporate climate-proof strategies and measures (e.g. to cope with an abundance of rainwater) into its municipal structure plan [8]. It would be misguided to blame spatial planning; rather, balancing various spatial issues - whether they be long- or short-term issues-is an inherent feature and task of planning. Planners may not overestimate or underrate certain spatial demands [9]-[11]. But the fact that climate measures are both controversial and a weak interest demands that they be given particular attention in planning decisions.

\subsection{Multifaceted Character}

The third challenge is the multifaceted character of climate adaptation. As climate change can result in dry pe- 
riods as well as extremely wet periods, the opposite sides of the same coin have to be addressed. This situation can be seen in Australian experiences, where changing climate has already led to more dry periods with bush fires on the one hand and to more severe flooding on the other hand. Also, in Central Europe, opposite extremes in the effects of climate change have been seen: while 2002 witnessed an extreme flood, 2003 saw the navigability of the Rhine river threatened due to a drought. On the city level, this multifaceted characteristic of climate change requires measures preparing for vastly different situations-this makes implementing adaptation measures more complex, varying in application from urban heat island problems to flooding problems as a result of heavy rainfall. This means that the effects of certain measures might have unforeseen and probably contradictory results. Climate adaptation can thus become a "wicked problem" [12] because the solution to one problem might be the cause of another problem. Since climate change tends to connect to many other domains and functions, it is not hard to imagine its far-reaching effects on a local level.

So, three challenges rise from implementing climate adaptation measures: the measures are uncertain in their effect, in competition with other interests, and multifaceted. Coping with these challenges is crucial for successfully pursuing the ideal of climate-proof cities.

\section{The Institutional Framework: Integrating Climate Change Adaptation into Urban Planning in the Netherlands}

What does climate adaptation mean for urban planning at the local level? To facilitate understanding of the impact of climate change on the underlying planning paradigm, this section briefly recaps the development of urban planning in the Netherlands over the past decades before addressing how the three challenges mentioned above can be dealt with in Dutch urban planning.

In the Netherlands, from the 1920s onwards, there has been a growing concern that urban expansion would engulf the whole western part of the Netherlands, forming one huge conurbation [13]. In reality, this was never a serious threat until the 1960s. Then, a major wave of suburbanization threatened to spread pockets of urban land use across the Green Heart [14]. From the late sixties onwards, social circumstances began to change. In this period, pressures from different interest groups succeeded more and more in convincing the authorities to focus attention on predominantly social objectives in urban policy.

The development, as described above, was mirrored in planning documents from the central government. The Second Report on Physical Planning in the Netherlands [15], for example, included a proposal to divert populations from the crowded western part of the country to the north and south. But it also took a powerful stand against the suburban sprawl that was developing into a real threat, particularly in the Green Heart [14]. The proposed alternative was to channel suburbanization into "concentrated deconcentration". More specifically, this meant accommodating new urban growth outside of the existing cities in a number of designated overspill centres. Jenks et al. [16] described this policy as a feasible compromise between concentration and low-density dispersal of urban activities. In Randstad, Holland, it was put into practice in the late 1970s and the early 1980s. Compact urban development has remained the cornerstone of Dutch physical planning ever since. In the view of Faludi and van der Valk [13], the policy of concentrated deconcentration was successful; half a million people moved into the designated growth centres, and urban sprawl was stemmed by prohibiting the growth of villages in the Green Heart.

In the course of the 1980s, the policy of compact urban development changed track. The main cause of the shift was the decline of the old urban cores. Concern about urban decay was first voiced by the cities' administrations. Later the issue was placed on the national political agenda [17]. City officials blamed inner city decline, in part, on the policy of concentrated deconcentration. Eventually, this policy was abolished. In its place, a new concept of compact urban growth has been developed and put into practice. Under this new policy, the government tries to guide new urban (re)development towards locations within existing cities (towards "brown" sites) and later on towards new greenfield sites directly adjacent to the cities of Amsterdam, Rotterdam, The Hague, and Utrecht. Within a ten-year period, a total of some 227,200 dwellings should be built on these sites in a relatively compact form. In addition, places of work and service premises will also be built [18].

This short recapitalization of Dutch urban planning illustrates, against the background of the issue of climate change, the intense shift in urban planning, namely, the shift from a brand of urban planning focused on economic growth towards a more sustainable approach.

In the course of developing the ideal for compact urban growth, a heated debate on the merits, feasibility, and 
costs of such growth has started throughout administrative and policy circles. The arguments used are reminiscent of those brought forward in the international literature on urbanization processes [19]. The debate shows that the implementation of urban development will not be an easy task, even if a broad consensus on its merits exists [16]. Within these urbanization processes, the Dutch governance approach already tries to balance too many interests, and the introduction of the need to adapt to the effects of climate change further complicates an already very complex decision-making process.

\section{Dilemmas of Integrating Climate Adaptation}

Based upon the earlier-mentioned challenges, it is possible to identify four dilemmas of integrating climate adaptation measures in urban planning processes. These dilemmas are addressed below.

\subsection{Dilemma of the Law: Flexibility versus Robustness}

Together, the three previously discussed challenges seem to demand flexibility, learning, and experiments from a governance approach [20] [21]. Some even propose flexible coalitions between all kinds of societal actors [22] [23] or bottom-up processes of self-organization aimed to increase the resilience of a local community towards climate change [24]. Such approaches, however, largely neglect issues like legal responsibility, liability and legal security, which are essential for a functioning spatial development [25] [26]. Adaptation to climate change demands not only flexibility but also robustness and reliability of spatial planning decisions [2] because planning processes must always strike a balance between the desire to change the built environment and the obligation to support legal certainty for those who have possessions in that particular area [25]. Impacts of climate change are always locally measured and tackled and therefore have to be locally tailor-made [27], responding to the institutional arrangements of the local urban planning system. Hence, in order to be effective and balance flexibility and robustness, adaptation needs to match the institutional arrangements for planning and fit into the local planning processes [1].

Accordingly, in order to deal with the challenges of climate adaptation, the planning system needs a legal system that is firmly rooted in broadly accepted values as well as flexibility to adjust to local circumstances. This can be considered the backbone of the governance approach needed to adapt to climate change. It, more or less, guarantees continuity and legal certainty in otherwise unpredictable processes. It must guarantee a minimum quality and cannot be too detailed. In the latter respect, the Dutch system does not fit this requirement because the detailed legal system sets limits to the much-needed flexibility in urban planning.

\subsection{Dilemma of Applying Principles of Decision-Making to Climate Adaptation Measures}

In the implementation of climate adaptation measures, three principles of decision-making must be considered: the precautionary principle, the proportionality principle, and the cost recovery principle [2].

The precautionary principle applies for situations that are difficult to grasp or calculate and for which negative effects of an acuity or event are likely but not yet sufficiently proven by scientific evidence. In such situations, the principle demands that decision makers may not defer measures that avert or reduce the potential damage on the basis of insufficient evidence [28] [29]. Their decision is thus based on discretion rather than measurable facts [29]. This principle, however, requires that the issues at stake are on the agenda of decision makers and, moreover, "that this agenda has a high priority" [28]. The precautionary principle is applied in many international treaties, but it can also be found in Dutch law [29].

The proportionality principle also gives a guideline for deciding specific measures. Measures need to match three requirements: they must be suitable to protect the interest at stake (there needs to be a causal relationship), they must be the least restrictive choice (compared to alternatives), and "the restriction caused by the measure must not be out of proportion to the objective pursued" [30]. This, of course, competes with the three challenges earlier mentioned, in particular the first two: the uncertainty of the effects measures may have and their competing character.

Third, the cost recovery principle implies that all costs of a measure need to be covered by one form of revenue. In environmental issues (climate adaptation can be considered as such), the "polluter pays principle" is applicable as cost recovery. It fulfils an informational, steering, and financing function [31]. The difficulty with climate adaptation is that the polluter often cannot be clearly identified. Even the beneficiary of climate adapta- 
tion measures is not always evident, which is a consequence of the multifaceted character of climate adaptation.

So, each of these principles plays an important role in every decision-making process about adaptation towards climate. Ideally, these principles should play a fairly equal role in each planning process. However, as shown above, these principles all have difficulties associated with them that affect how challenges of climate change should be approached.

\subsection{Dilemma of Technical Safety Standards: Protection versus Moral Hazard}

While the above principles can be applied to climate adaptation, most of them also sustain technical safety standards (such as design levels for flood protection), as these are the best justifiable solutions according to the precautionary principle, the principle of proportionality, and the cost recovery principle.

Generally, it will be expected that the use of such standards will raise the general physical quality of an area. Yet, the use of norms is in conflict with the need for flexibility in specific local circumstances. Especially in situations of uncertainty and complexity, flexibility in planning rules and norms is essential [32].

The dilemma with technical safety standards is the following: such standards are politically approved and very common in environmental policy, for example, in the European Water Framework Directive or the European Air Quality Directive, but they are also common in flood risk management [33]. These standards are essential for building structures like levees, measuring dams and polders, sizing drainage systems, or drawing flood risk maps [34]. A safety standard determines the maximum impact on the subject of protection, such as the maximal reasonable pollution or damage. However, reasonable impact events also need to be determined. In this context, "reasonable" means that the severity of an event must not exceed a determined impact on the values. This indicates that the technical measure would have to protect against rare but heavy events while also tolerating frequent smaller events. Most real-world applications, however, fall short of this idea. Often, technical measures protect against small and frequent events and fail against infrequent and heavy events. This can be seen in the use of dikes against flooding [33] or the famous Dutch barriers, the "Deltaworks", against storm floods. Moreover, security cannot be guaranteed by technical safety standards, but they provide the illusion of security [35]. Such technical safety standards provoke additional value accumulation, because people feel safe behind them and become complacent [36]-[38]. In environmental research, this dilemma is called a moral hazard [28] [39].

\subsection{Dilemma of Science and Knowledge: Facts versus Social Constructions}

Scientific information might seem to play a role in unraveling the complexity of applying climate adaptation measures. Yet, research shows that scientific information in general (including GIS tools) is not easily incorporated into planning processes [40] [41]. This applies even more so for information about the effects of climate change. Ren et al. [8] concluded from their study on the Dutch city of Arnhem, "The existing gap between the practical world of spatial planning and the scientific world of climate studies will never be closed. The tool remains just a fragile bridge to cover a huge gap".

To bridge the gap Ren described, the earlier-identified challenges must be met [8]. It is necessary to organize the support of the different actors that have a stake in the adaptation process towards climate change. A first requisite is the use of a common knowledge base. Without an agreement between the relevant actors as to the basic analysis of the common problems that must be addressed, there is no chance of a (common) solution. The information from the analysis of urban climate maps can provide not only this knowledge, but it can also provide a common "language" about the effects of climate change. If the relevant actors agree upon language and analysis, the necessary basis is created for common solutions-although these requirements do not necessarily and automatically lead to consensual solutions [42].

\section{Capacity Building in a Three-Stage Procedure}

The key question that remains is how to organize these solutions. The section above identified four dilemmas: First, coping with the requirement for flexible governance schemes on the one hand while also providing legal security for the implementation of measures on the other hand; second, applying principles of decision-making to climate adaptation; third, managing technical quality standards on the one hand and avoiding their moral hazards on the other hand; and fourth, balancing measurable knowledge with a socially constructed common un- 
derstanding of the problem.

This leads to the next question: How can public and private actors be mobilized in order to develop such an adaptation strategy?

It is important to realize that a new adaptation strategy has to be integrated into an existing (and functioning) urban planning system. A strategy, firmly supported by a common understanding of the effects of climate change, starts with building common ground, which can function as a basis for the development of "goal entwinement" [1]. This can be understood as capacity building. The core characteristic of goal entwinement is the acceptance of differences between actors [43]. This acceptance provides a basis for a cooperative attitude between actors and the creation of opportunities, for example, sharing costs and resources in the case of an integrated design for area development. In fact, the introduction of climate-proof elements can provide benefits for public actors as well as for private actors because it can easily be embedded as replacement investments in day-to-day issues in urban planning, such as maintenance issues [1]. Thus, not only the urban quality improves, but also the value of the real estate involved may increase. The latter implies not only a positive incentive for the owner, but also for municipalities as it may result in higher revenue from the property taxation [44]. So, this acceptance might be able to prevent conflicts of interest.

Analytically, three stages can be distinguished in such a strategy: awareness, recognition, and urgency. The process always starts by generating an awareness of the problem. It is easy to see how the role of information and science fits into this stage. In Rotterdam, in the case of Feijenoord (an unembanked neighbourhood), the local government made the first step towards awareness by bringing public and private parties together in "expert meetings". In interviews, the participants stated they were satisfied with these meetings but that more steps should be taken [1]. The latter statement showed that recognition of the problem was around the corner but not yet reached. The same is true for a sense of urgency, although the ever-present threat of flooding in Feijenoord ensures a constant sense of urgency in this particular unembanked neighbourhood.

The stage of awareness must lead to recognition of the problem, as the case of Feijennoord shows. This recognition, in its turn, has to be translated into some sense of urgency. For, without recognition, the problem will be denied, and without some sense of urgency, there will be no need for policy actions. In both cases, nothing will happen. A common recognition of the problem in combination with a common sense of urgency are the basic conditions for a joint strategy that can bring about the adaptation towards climate change within urban planning processes.

In the third stage, a common strategy can be developed in which priorities are set, instruments developed, and investment schemes agreed upon. The case of Feijenoord showed the mutual dependency of market parties and local officials. Both perceived a shared responsibility towards climate change [1]. However, the Feijenoord case also showed that a hierarchical steering by public actors strengthened the dissatisfaction of market parties in this process. From a traditional water management perspective, this type of steering is understandable, because it refers to (legal) certainty and equality of rights, which is strongly embedded in water policy in the Netherlands. This third stage can, however, benefit significantly if the strategy is based upon the three principles mentioned above because, in that case, it is optimally tailored to the issues as well as to the governance context in which it has been developed. The case of Feijenoord shows that small, flexible measures in public space support growth in trust between public and private partners [1], as do protective measures in vulnerable public areas. On the other hand, the same study shows that it seemed hard to gain trust through larger projects, such as the elevation of land.

\section{Conclusions: Soft Interests in a Hard Process}

Why is such a careful arrangement for adapting to climate change in urban planning necessary? One has to keep in mind that the relevant actors will first view the development of an adaptation strategy as no more than some form of external integrative interest that is eager to penetrate into the urban planning system, as so many sorts of interests do all the time. From this perspective, the attempt will trigger all the usual defense mechanisms. One may expect a lot of opposition to any attempt to start an adaptation strategy due to its more disagreeable characteristics [2]. Consequently, it will be interpreted as an extremely weak interest without an economic and/or financial position to back it up. Its long-term character and weak financial position will especially put any adaptation strategy in urban planning in this relatively weak position because relevant actors will first see the associated extra costs for an issue of lower priority. 
However, if a carefully laid out strategy, organized in stages, is accompanied by support from higher tiers of government, this position can change significantly [45]. As ideological arguments (with a weak economic impact) work better on higher administrative levels of government, it should be possible to arrange support. As pragmatism rules the lower tiers of government, a lot of support is needed to overcome the existing (and new) barriers to make the adaptation towards climate change in urban planning a success. Although this road may appear a tedious one, it is nevertheless an exciting challenge in which both practitioners as well as scientists can play an important role.

\section{Acknowledgements}

This research project has been carried out within the framework of the Dutch National Research Programme "Knowledge for Climate" (www.knowledgeforclimate.org) (KFC), theme: Climate-Proof Cities (CPC).

\section{References}

[1] Kokx, A. and Spit, T. (2012) Increasing the Adaptive Capacity in Unembanked Neighbourhoods? An Exploration into Stakeholders' Support for Adaptive Measures in Rotterdam. American Journal or Climate Change, 1, 181-193.

[2] Uittenbroek, C., Janssen-Jansen, L., Runhaar, H.W., Salet, W. and Spit, T. (2014) Identification of the Various Beliefs on Climate Adaptation within Dutch Municipalities: A Comparative Case Study of Amsterdam, the Hague and Rotterdam. Environmental Politics, Forthcoming.

[3] van Buuren, A., Driessen, P., van Rijswick, M., Rietveld, P., Salet, W.P.J. and Spit, T. (2013) Towards Adaptive Spatial Planning for Climate Change: Balancing between Robustness and Flexibility. Journal for European Environmental \& Planning Law, 10, 29-53. http://dx.doi.org/10.1163/18760104-01001003

[4] Fleischhauer, M. (2004) Klimawandel, Naturgefahren und Raumplanung. Ziel- und Indikatorenkonzept zur Operationalisierung räumlicher Risiken. Dortmunder Vertrieb für Bau- und Planungsliteratur, Dortmund.

[5] Pasche, E. (2012) Risikomanagement statt Hochwasserschutz von Küstenstädten in Zeiten des Klimawandels. Energieeffizienz von Gebäuden. http://www.hochwasser-nord.de

[6] Gough, I., Meadowcroft, J., Dryzek, J., Gerhards, J., Lengfeld, H., Markandya, A. and Ortiz, R. (2008) JESP Symposium: Climate Change and Social Policy. Journal of European Social Policy, 18, 325-344. http://dx.doi.org/10.1177/0958928708094890

[7] Giddens, A. (2009) The Politics of Climate Change. Polity, Cambridge, Malden, MA.

[8] Ren, C., Spit, T., Lenzholzer, S., Yim, H.L.S., Heusinkveld, B., van Hove, B., Chen, L., Kupski, S., Burghardt, R. and Katzschner, L. (2012) Urban Climate Map System for Dutch Spatial Planning. International Journal of Applied Earth Observation and Geoinformation, 2012, 207-221. http://dx.doi.org/10.1016/j.jag.2012.01.026

[9] Hartmann, T. (2009) Clumsy Floodplains and the Law. Towards a Responsive Land Policy for Extreme Floods. Built Environment, 35, 531-544. http://dx.doi.org/10.2148/benv.35.4.531

[10] Taekema, S., de Roo, A. and Elion-Valter, C. (2011) Understanding Dutch Law. Eleven International Publishing, The Hague.

[11] Needham, B. (2007) Dutch Land Use Planning. Planning and Managing Land Use in the Netherlands, the Principles and the Practice. SDU Publishers, The Hague.

[12] Rittel, H.W. and Webber, M.A. (1973) Dilemmas in a General Theory of Planning. Policy Sciences, 4, 155-169. http://dx.doi.org/10.1007/BF01405730

[13] Faludi, A. and van der Valk, A.J. (1990) De groeikernen als hoekstenen van de Nederlandse ruimtelijke planningdoctrine. Van Gorcum, Assen.

[14] Dieleman, F.M. and Musterd, S. (1992) The Randstad: A Research and Policy Laboratory. Kluwer, Dordrecht.

[15] Ministry VRO (Housing and Physical Planning) (1996) Second Report on Physical Planning in the Netherlands. Ministry of Housing and Physical Planning, The Hague.

[16] Jenks, M., Burton, E. and Williams, K. (1996) The Compact City: A Sustainable Urban Form? E \& FN Spon, London.

[17] Ministry VROM (1993) Structuurschets Stedelijke Gebieden. Ministry of Housing, Physical Planning and the Environment, The Hague.

[18] Spit, T. and Zoete, P.R. (2009) Ruimtelijke ordening in Nederland. Een wetenschappelijke introductie in het vakgebied. Sdu uitgevers, The Hague.

[19] Richardson, H.W. and Bae, C.C. (2004) Urban Sprawl in Western Europe and the United States. Ashgate, Farnham, Surrey. 
[20] Folke, C., Hahn, T., Olsen, P. and Norberg, J. (2005) Adaptive Governance of Social-Ecological Systems. Annual Review of Environment and Resources, 30, 441-473. http://dx.doi.org/10.1146/annurev.energy.30.050504.144511

[21] Huitema, D., Mostert, E., Egas, W., Moellenkamp, S., Pahl-Wostl, C. and Yalcin, R. (2009) Adaptive Water Governance. Assessing the Institutional Prescriptions of Adaptive (Co-)Management from a Governance Perspective and Defining a Research Agenda. Ecology and Society, 14, 26.

[22] Brunner, R.D. (2005) Adaptive Governance. Integrating Science, Policy, and Decision Making. Columbia University Press, New York.

[23] Pahl-Wostl, C. (2006) Transitions towards Adaptive Management of Water Facing Climate and Global Change. Water Resources Management, 21, 49-62. http://dx.doi.org/10.1007/s11269-006-9040-4

[24] Boonstra, B. and Boelens, L. (2011) Self-Organization in Urban Development: Towards a New Perspective on Spatial Planning. Urban Research \& Practice, 4, 99-122. http://dx.doi.org/10.1080/17535069.2011.579767

[25] Hartmann, T. and Needham, B. (2012) Planning by Law and Property Rights Reconsidered. Ashgate, Farnham, Surrey.

[26] Needham, B. (2006) Planning, Law, and Economics. The Rules We Make for Using Land. Routledge, Abingdon, Oxon.

[27] Blanco, H., Alberti, M., Forsyth, A., Krizek, K.J., Rodríguez, D.A., Talen, E. and Ellis, C. (2009) Hot, Congested, Crowded and Diverse: Emerging Research Agendas in Planning. Progress in Planning, 71, 153-205. http://dx.doi.org/10.1016/j.progress.2009.03.001

[28] Elling, B. (2008) Rationality and the Environment. Decision-Making in Environmental Politics and Assessment. Earthscan, London.

[29] Backes, C.W. and Verschuuren, J.M. (1998) Precautionary Principle in International, European, and Dutch Wildlife Law. Colorado Journal of International Environmental Law and Policy, 34, 43-70.

[30] Prechal, S. (2008) National Applications of the Proportionality Principle-Free Movement and Procedural Requirements. Proportionality Reconsidered. Legal Issues of Economic Integration, 35, 201-216.

[31] Unnerstall, H. (2006) The Principle of Full Cost Recovery in the EU-Water Framework Directive-Genesis and Content. Journal of Environmental Law, 19, 29-42. http://dx.doi.org/10.1093/jel/eql038

[32] Bohensky, E. and Lynam, T. (2005) Evaluating Responses in Complex Adaptive Systems: Insights on Water Management from the Southern African Millennium Ecosystem Assessment (SAfMA). Ecology and Society, 10, 11.

[33] Vogt, M. (2005) Hochwassermanagement und räumliche Planung. In: Jüpner, R., Ed., Hochwassermanagement, Shaker, Aachen, 97-118.

[34] Strobl, T. (2006) Wasserbau. Aktuelle Grundlagen-neue Entwicklungen. Springer, Berlin.

[35] Assmann, A. (2001) Dezentraler, Integrierter Hochwasserschutz-vom Konzept zur Planung. In: Heiden, S., Erb, R. and Sieker, F., Eds., Hochwasserschutz heute-nachhaltiges Wassermanagement, E. Schmidt, Berlin, 197-236.

[36] Greiving, S. (2002) Räumliche Planung und Risiko. Gerling-Akademie Verlag, München.

[37] Patt, H. (2001) Hochwasser-Handbuch. Auswirkungen und Schutz. Springer, Berlin. http://dx.doi.org/10.1007/978-3-642-56923-4

[38] Hartmann, T. (2011) Clumsy Floodplains. Responsive Land Policy for Extreme Floods. Ashgate, Farnham, Surrey.

[39] Renn, O. (2008) Risk Governance. Coping with Uncertainty in a Complex World. Earthscan, London.

[40] Geertman, S. (2006) Potentials for Planning Support: A Planning-Conceptual Approach. Environment and Planning B: Planning and Design, 33, 863-880. http://dx.doi.org/10.1068/b31129

[41] Brömmelstroet, M.T. (2009) Commentary. The Relevance of Research in Planning Support Systems: A Response to Janssen et al. Environment and Planning B: Planning and Design, 36, 4-7. http://dx.doi.org/10.1068/b3601com

[42] Billé, R. (2008) Integrated Coastal Zone Management: Four Entrenched Illusions. Surveys and Perspectives Integrating Environment and Society, 1, 75-86.

[43] Hartmann, T. (2012) Wicked Problems and Clumsy Solutions: Planning as Expectation Management. Planning Theory, 11, 242-256. http://dx.doi.org/10.1177/1473095212440427

[44] Root, L., van der Krabben, E. and Spit, T. (2014) Bridging the Financial Gap in Climate Adaptation: Dutch Planning and Land Development through a New Institutional Lens. Journal of Environmental Planning and Management, (forthcoming). http://dx.doi.org/10.1080/09640568.2014.885412

[45] Driessen, P.P.J. and Spit, T. (2010) De bekostiging van klimaatadaptatie: Argumenten voor een legitieme balans van baten en lasten. Beleid en Maatschappij, 37, 73-84. 
Scientific Research Publishing (SCIRP) is one of the largest Open Access journal publishers. It is currently publishing more than 200 open access, online, peer-reviewed journals covering a wide range of academic disciplines. SCIRP serves the worldwide academic communities and contributes to the progress and application of science with its publication.

Other selected journals from SCIRP are listed as below. Submit your manuscript to us via either submit@scirp.org or Online Submission Portal.
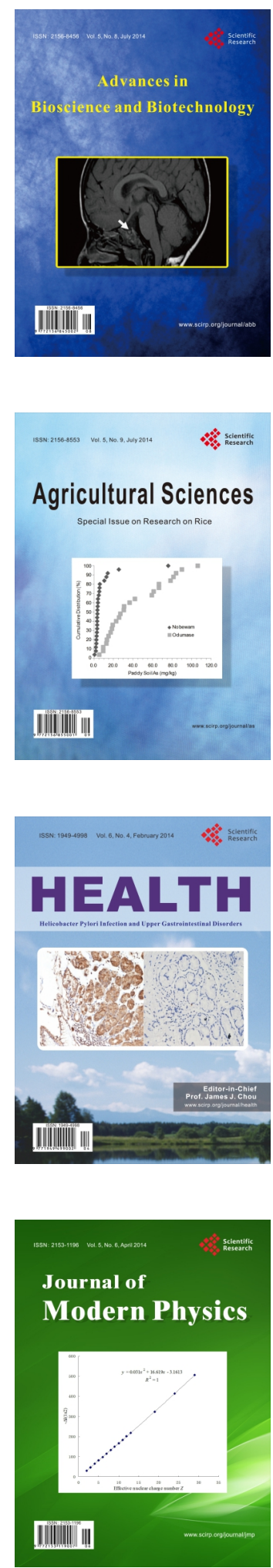
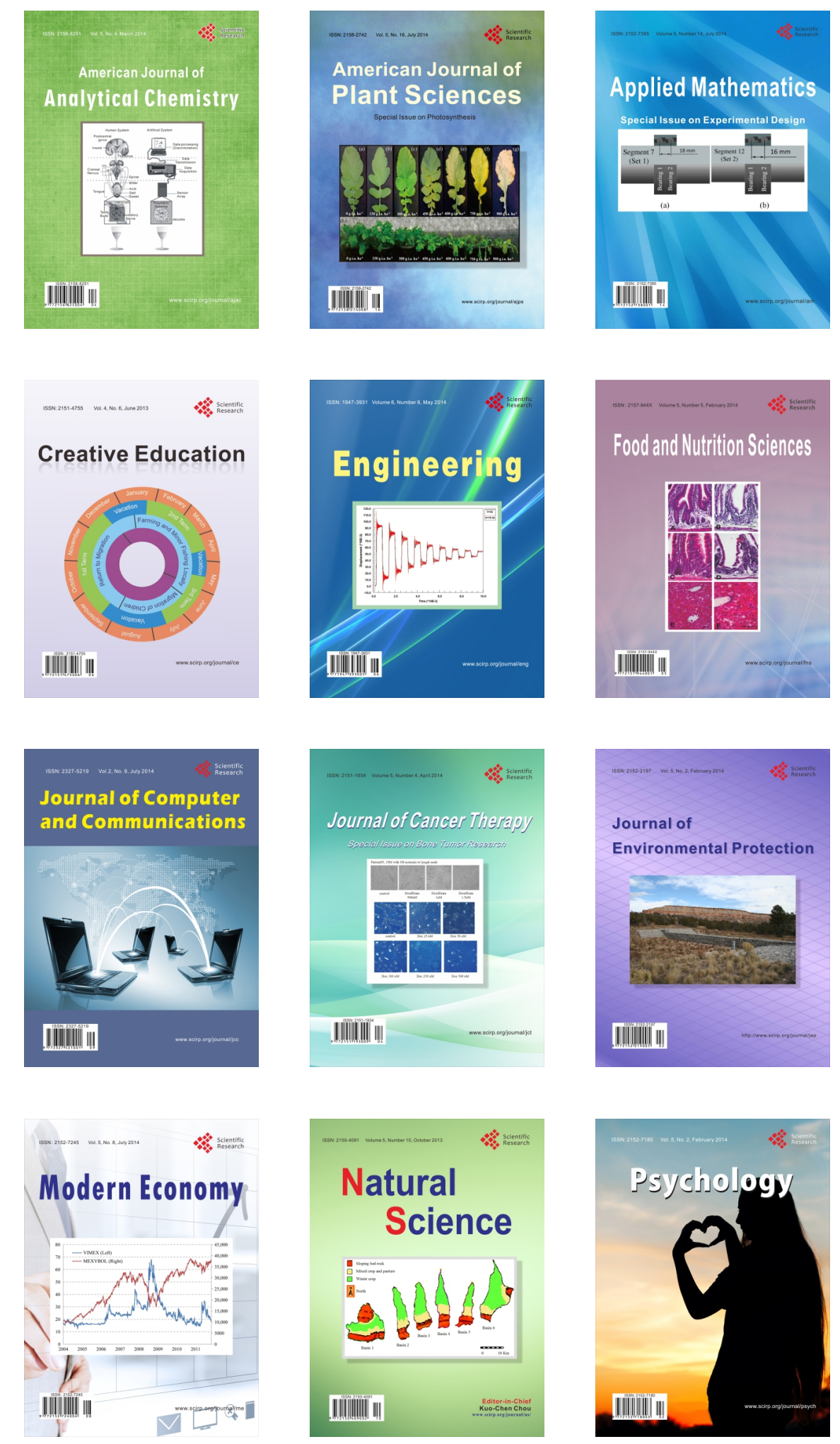